\title{
Characteristic Ideal Form to Architecture Traditional Makassar with to Humanist Shelter Development in Settlement Bricks Processor at Gowa Resident, South Sulawesi
}

\author{
Imriyanti $^{1, *}$, Shirly Wunas ${ }^{1}$, Mimi Arifin ${ }^{1}$, and Idawarni J. Asmal ${ }^{1}$ \\ ${ }^{1}$ Hasanuddin University, Indonesia
}

\begin{abstract}
The ideal form architecture traditional Makassar there is to ideology form, function and architecture mean. Form, function and mean can is known to utilization macro space and micro space at house traditional Makassar. Architecture traditional being culture identity tribes because in there is life society. The society traditional Makassar it is that society still holding long habit by true in daily life. Humanist shelter referring to human needs especially to the occupants, there are human needs that connected with that environment, is sense of security, comfortable, hygienic and economic. The settlement bricks processor at Gowa resident identic with shelter traditional but with growth development in various ways sector than change shelter bricks processor too experiencing good change from at form, function and mean. The settlement bricks processor to Iowa resident at being exactly in Dusun Giring-Giring Kalase Rena village, Bontolangkasa village and Maccini baji village. The change form, function and mean to house/shelter bricks processor than the problem and that found how is ideal form architecture traditional Makassar there is development humanist shelter in settlement risks processor at Gowa resident. This research purpose is element analysis ideal form architecture traditional Makassar that is can to shelter bricks processor at Gowa resident. This research in descriptive explore. The tory character that is done by direct observation to house/shelter bricks processor at Gowa resident. The results of this study that shows ideal form architecture traditional Makassar there is to macro space a house traditional Makassar in settlement bricks processor at Gowa resident. Ideal form to macro space architecturetraditional Makassar there is to house orientation, patterns of home footprint with to utilization as bricks processor at Gowa resident. With utilization macro space at house traditional Makassar can then to form humanist shelter for bricks processor at Gowa resident, South Sulawesi.
\end{abstract}

Keywords: ideal form, architecture traditional Makassar, humanist shelter, settlement bricks processor

\section{Introduction}

Culture in Indonesia is very diverse and has its own characteristics and character in each region. Culture consists of everything that is learned from the needs, the normative patterns of my manners, that is to include all the ways or patterns of thinking, feeling and human acting. The needs of society are largely fulfilled by the human ability in cultures which is the result of his creations to meet all his needs. (Soerjono and Sulistyawaty, 2014).

Culture owned by each region has one characteristic through its traditional architecture in an integrated manner. Traditional architecture is one element of culture that grows and develops along with the growth of a tribe. Traditional architecture is the cultural identity of a tribe, because it contains all the life of society.

The existence of traditional architecture is closely related to the daily life of the people who still adhere to the collective life order, that is to have harmony and harmony between the macrocosm (universe) and the microcosm (building) (Soeroto, 2002). In the traditional architecture is contained in an integrated form of ideal, social form and material form of a culture (Mardanas, 1985). The form of culture is a system of ideas, concepts and results of human activities.

The development of cultural values of a region is able to strengthen the identity of the community or community groups and become one of the preconditions of creating a space of meaning in the dwelling which has a function in the utilization by the residents of the house. In the residential area of the bricklaying management of Gowa regency dominant inhabitants of Makassar tribe which has the ideal form in its traditional architecture is the shape of the stage house inhabited macro changes, so this raises the problem that is how the ideal form of traditional architecture of Makassar to the development of humanis housing in settlement settlements brick district of Gowa, this is connected with the profession of society as pengelolah brick that can form a modern

*Corresponding author: imrianti@gmail.com 
dwelling. The settlement of brick management in Gowa Regency is located in Dusun Giring-Giring, Bontolangkasa Village, Bontonompo Sub-District and Maccinibaji Village, Bajeng Sub-District. These three locations are the largest brick producing areas in the province of South Sulawesi.

\section{Culture Concept In Traditional Architecture}

Culture is a commonality and unity for the people of a region and at the same time become a human character in shaping individual behavior and personality. Culture has a big function for people and society. (Soekanto and Sulistyowati, 2014). Culture is a very broad of the life of society so that culture can be a character that is required by every individual and make a stage of life development of each community group in the form of activities.

To manifest individual human characters can be in form through activities or human activities themselves so that formed in an ideology embodied in the form of his work. Human works are reflected through the social culture of society as a whole.

Rapoport in Altman et al., (1980), dividing the culture into three main views. First, culture as a way of life is the same from a group. Second, as a system of symbols or symbols transmitting through symbolic codes. Third, as an adaptive strategy unit to survive, relate to ecology and resources. Man's work embodied in a socio-cultural form is reflected in the ideology expressed in his daily life in a place or space. The statement of space and time of all life of a cultured society is revealed in architecture. Traditional architecture is the embodiment of the culture and thought patterns of reflection in the relationship between the universe and the creator.

\section{Traditional Architecture of Makassar Tribe}

Traditional architecture is part of the policy and wisdom of living community development. Its existence is closely related to the daily life of the traditional society that still adheres to the collective life order. There is harmony and harmony between the macrocosm (universe) and the microcosm (building) that must always be nurtured (Soeroto, 2003). Traditional society in question is a society that still holds the old habits firmly in everyday life. Traditional societies are often regarded as a society that only lives in an atmosphere of solely ancestral beliefs that are influenced by exclusive local "cultural ethos" and have special characteristics.

Makassar tribe, is the name of a tribe that has a large population in Sulawesi. According to Wahid (2008), that the society of Makassar tribe as a unity of people who live together for a long time, hereditary by itself will show elements that are traditional. The tribal community of Makassar holds that the house is part of the traditional architecture that has the belief and think that life is only achieved when between the macrocosm and microcosm is always established a harmonious relationship. This view is reflected in Makassar traditional house in the form of a stage with a rectangular base shape.

\section{The Ideal Form}

The ideal form is part of the form of culture. The Ideal form have in common with ideology, where ideology is a collection of ideas and ideas derived systematically in a form. According to Destutt de Tracy, ideology can be regarded as a comprehensive vision as a way of looking at things in general in everyday life and in some directions philosophically (1796). The value of ideology in culture is indicated through cultural phenomena. According to J.J. Honingmann, there are three cultural phenomena, namely ideas, activities and artifacts (in to Koentjaraningrat, 1976). Koentjaraningrat offers four forms of culture, namely: culture as an ideological value; culture as a system of ideas; culture as a system of behavior and patterned actions; culture as a physical object (artifact) (Koentjaraningrat, 1976).

\section{Humanity Occupation}

Humane dwelling has a meaning as a place of settlement that leads to humanity and can be united with the earth or the environment. The influence of humanism in architecture, present strongly in the era of modern architecture. Architecture when it looks very trying to humanize the architecture, by looking at human needs in the world. Humanisme bringing a state that points to all human needs must be obeyed regardless of anything else. According to Hali (2008), humanism is a plot of discourse that constantly reminds and defends human beings as the main agent of choice for one's own life.

\section{Methodology}

This research is a descriptive explorative and interpretative study that study theoretically by observing directly the ideal form of brick processing settlement in Gowa regency of South Sulawesi. The ideal form observed is the macro space of brick management settlements in Gowa district. For the macro space observed is the orientation direction of the dwelling, the pattern of the home foot brick management

Population is the whole object that is the source of information / data (Yusuf, M; 2015) argued that the population is a generalization region consisting of objects / subjects that have certain qualities and characteristics set by the researcher to be learned and then in conclusion. According to Lexy. M.J (2001) argue that, with regard to the size of the population that a researcher is concerned, it is necessary to distinguish between two different populations: experimental or observationally accessible populations and target populations. The population of this research is in Dusun 
Giring-Giring of Kalase'rena Village and Bontolangkasa I Village of Bontonompo Subdistrict and Maccainibaji Village of Bajeng Sub-District of Gowa Regency.

Sample were taken from all three locations or populations. According to Prasetyo (2005), sample quantities can be determined based on the Slovin formula. The sample taken purposively were carried out on sample of pinggawa houses and pajama houses, as these two samples were the main sample of research related to brick-making work.

Pinggawa and pajama house consist of traditional houses (house on stilts), mixed house (house on stilts together with stone house) and modern house (house made of stone structure). For Dusun Giring-Giring the number of sample is 64 house, Bontolangkasa Village as many as 88 house and Maccinibaji Village 78 house.

Rumah pinggawa dan pajama terdiri dari rumah tradisional (rumah panggung), rumah campuran (rumah panggung yang menyatu dengan rumah batu) dan rumah modern (rumah yang strukturnya terbuat dari batu). Untuk Dusun Giring-Giring jumlah sampelnya 64 rumah, Desa Bontolangkasa sebanyak 88 rumah dan Desa Maccinibaji 78 rumah.

\section{Discussion}

\section{Location of Bricklaying in Gowa Regency of South Sulawesi}

Brick processing settlements in Gowa regency, the Giring-Giring village of Kalaserena village, Bontonompo sub-district, Bontolangkasa village, Bontonompo district and Maccinibaji village, Bajeng sub-district. The location of this study is an area that has brick-making materials from the natural resources of the environment such as in Dusun Giring-Giring and Desa Maccinibaji while Bontolangkasa Village purchases natural resources / stone-making material from Maccinibaji Village.

These two sub-districts are sub-districts that have a clay excavation area based on the License, Business Placements issued by the Gowa Head of Regional Administration in 1978. Gowa regency is a lowland area that has natural resources for development is very much including sand, clay, and gravel, all of which are the results of the mine class $\mathrm{C}$.

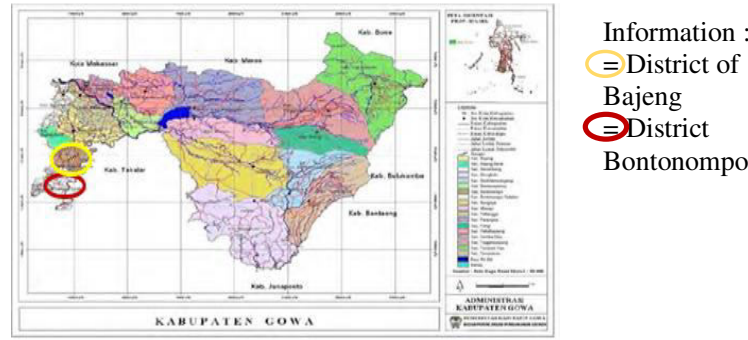

Fig. 1. Map of Gowa Regency Administration.

Source: LP2B Study of Gowa District of South Sulawesi, 2016.

Gowa Regency is located at 119.37730 West Longitude and 120.03170 East Longitude and
5,08293428620 North Latitude and 5.5773054370 South Latitude; where the area is located in the southern part of South Sulawesi Province with an area of $1,883.33 \mathrm{~km}^{2}$, or equivalent to $3.01 \%$ of the total area of South Sulawesi Province.

\section{Dusun Giring-Giring Village Kalase'rena District Bontonompo Gowa Regency.}

Dusun Giring-Giring Kalase'rena Village has a rice field area of 120 ha, 60 ha of land there are $2 \mathrm{RW}$ and $4 \mathrm{RT}$, the distance Giring-Giring Hamlet to the capital District $2 \mathrm{~km}$ and the distance to the capital District $21 \mathrm{~km}$. Population density is 1317 people, and the average number of household members is about 6 people.

Kalase'rena village is a plain area with boundaries:

North side : Bajeng Sub-district

East side : Takalar District

South side : Tamallayang urban village

West side : Bontolangkasa Village I

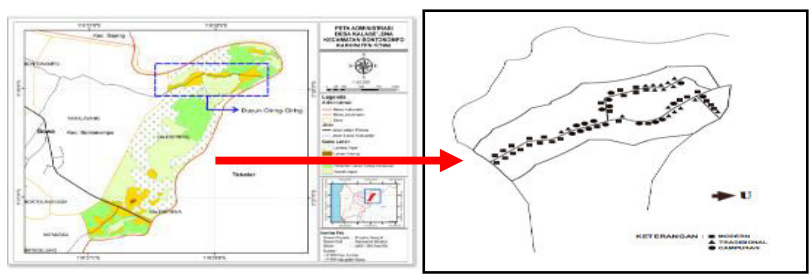

Fig. 2. Map of Kalase'rena Village and Map of Giring-Giring Hamlet (Source: LP2B Gowa District and Survey Result, 2017).

Natural Resources (SDA) brick material in the hamlet Giring-Giring Kalas'rena village can be obtained in the neighborhood of community settlements because this hamlet is in the highlands.

\section{Village Bontolangkasa I District Bontonompo Gowa Regency.}

The total area of Bontolangkasa village $\pm 2.45 \mathrm{~km} 2$ with the population density 1.127 per $\mathrm{km} 2$, this village has a tropical climate with irrigated rice fields. The village of Bontolangkasa is at an altitude above sea level of $19.00 \%$ with an area of $2.45 \mathrm{~km} 2$. The distance from Bontolangkasa village to the district capital $\pm 1 \mathrm{~km}$ and distance to the district capital $\pm 18 \mathrm{~km}$.

Bontolangkasa village with area the following limits:

North side $\quad$ : Kelurahan Tamallayang

East side : : Takalar District

South side : : Barembeng Village

West side : South Bontolangkasa Village 


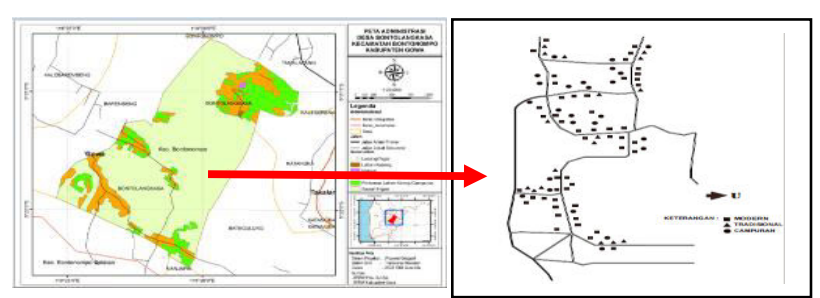

Fig. 3. Map of Village Bontolangkasa I District Bontonompo Gowa Regency

Source: LP2B Gowa District and Survey Results, 2017.

Percentage to sub-district by administrative of Bontolangkasa village is $8,06 \%$. Bontolangkasa village has 4 hamlets, $9 \mathrm{RW} / \mathrm{RK}$ and $16 \mathrm{RT}$, with a population of 2,683 people. Natural Resources (SDA) in the village of Bontolanagkasa I was obtained by buying from Maccinibaji village, Bajeng sub-district.

\section{Village Maccinibaji Bajeng District Gowa District}

Maccinibaji village is located in Bajeng District of Gowa Regency. The area of Maccini-baji village is $\pm 4.32 \mathrm{~km} 2$ with a population density of 1.045 per $\mathrm{km} 2$ of the total population of 4,513 people, this village has a tropical climate with irrigated and non irrigated rice field conditions. Maccinibaji village is at an altitude above sea level of $12.00 \%$ with an area of $7.19 \%$.

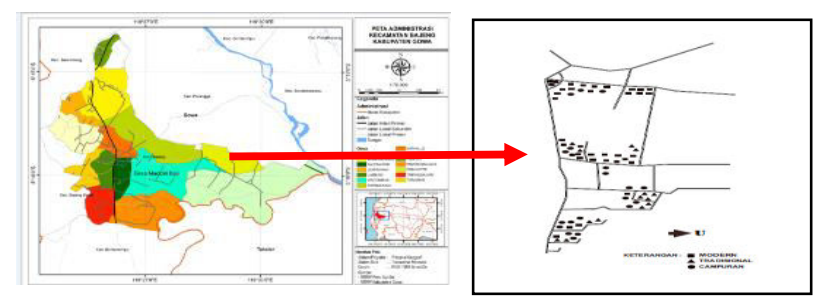

Fig. 4. Map of village administration Maccinibaji Bajeng District Gowa Regency

Source: LP2B Gowa District and Survey Results, 2017.

Maccinibaji Village Bajeng District is a highland area with the following limits:

North side : Pallangga District

East side : Paraikatte Village

South side : Panyangkallang Village

West side : Kalebajeng Village

The distance from Minasabaji village to the district capital $\pm 3 \mathrm{~km}$ and distance to the district capital \pm 15 $\mathrm{km}$. For brick material in Maccini Baji village, Bajeng sub-district is found in its residential neighborhood and sold to another village, one of them is Bontolangkasa village in Bontonompo district. Natural Resources (SDA) in the village of Maccinibaji Bajeng subdistrict is located in the community settlement area so that bricklayers can produce bricks and also sell brick material to Bontolangkasa village.

\section{Analysis of Macro Room in Ideal Orientation}

Table 1. Ideal Behavior through Home Orientation in Brick Plantation Areas of Gowa Regency.

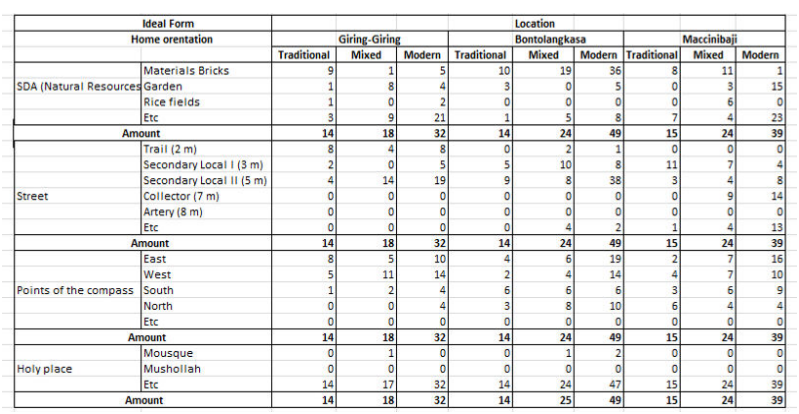

\section{Natural Resources}

Orientation of house with natural resource (Natural Resources) variable and indicator of material brick, garden, rice field and others.

In Dusun Gamping-Gamping Traditional house dominant leads to the source of brick material. Houses with mixed shapes and many modern leads others like the street. Brick material contained in the community settlement in Giring-Giring Hamlet so that brick making becomes a supporting livelihood besides farming and gardening in the hamlet.
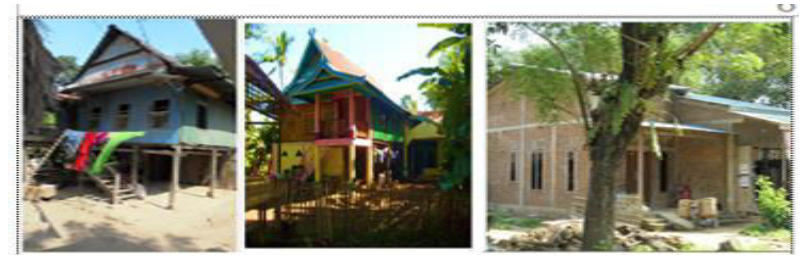

Fig. 5. Form of traditional, mixed and modern house in GiringGiring Hamlet.
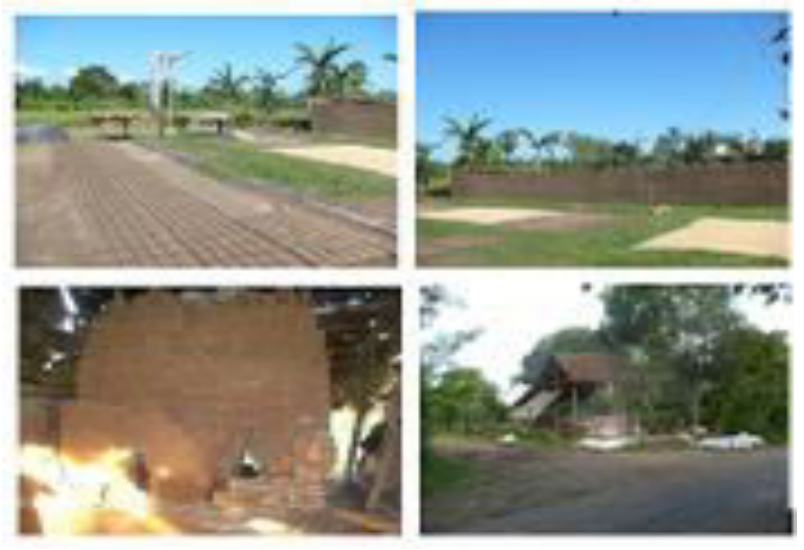

Fig. 6. Natural Resources (SDA) adjacent to brick processing in Giring-Giring Hamlet. 


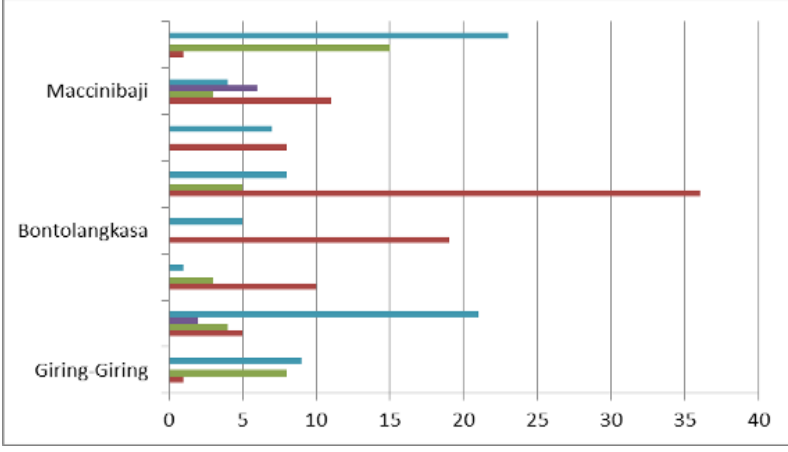

Fig. 7. Graph of home orientation towards Natural Resources.

Orientation of the house to the natural resources in the village of Bontolangkasa, as many as 36 houses in the modern form of natural resources leads to this matter is influenced by the placement of brick material in place in front of the house so the residents of the house can observe and simultaneously make a brick in the yard home.
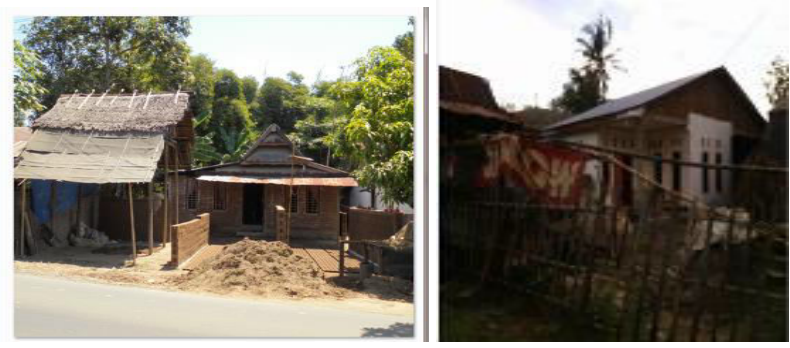

Fig. 8. Orientation of houses in Bontolangkasa village that leads to brick processing site.

In the village of Maccinibaji Bajeng subdistrict, the house with the modern form is not oriented to the SDA because in the village brick manufacturing is far from the brick processing house. While 11 houses mixed shapes and 8 traditional houses oriented to the natural resources.

\section{Street}

The orientation of the house that leads to the road in the three brick processing locations of Gowa Regency is dominant in the direction of the local, secondary, I and II roads but in Maccinibaji village there is a mixed and modern house that leads to the collector road as well as in Bontolangkasa and Maccinibaji villages. orientation to the neighbor's house because the pattern of settlements in the village is a centralized pattern.

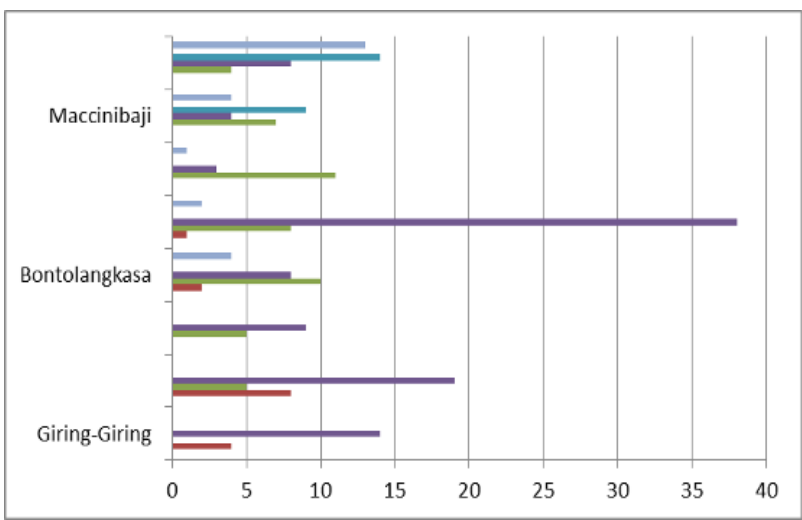

Fig. 9. Graph of house orientation to road in brick processing settlement of Gowa Regency.

\section{Points of the compass}

The orientation of the house to the winds in the three research sites tends to lead east, west and south but there are also traditional, mixed and modern houses heading north in the villages of Bontolangkasa and Mac-cinibaji villages but for brick-processing plants not facing north

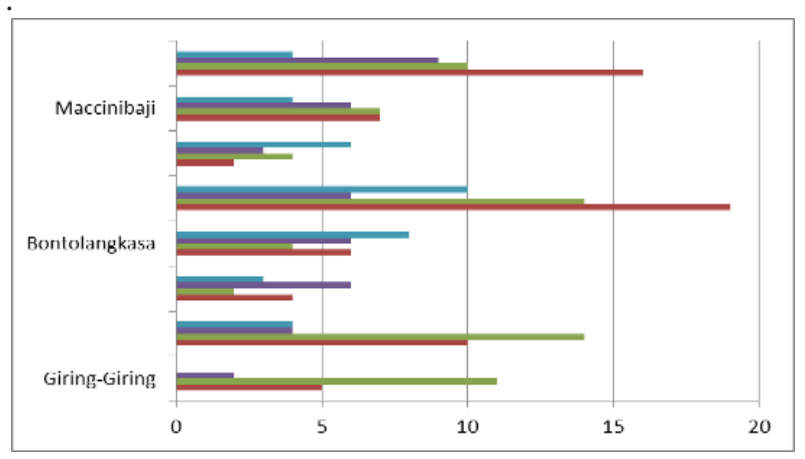

Fig. 10. Graph of home orientation toward the wind in the brick processing settlement of Gowa regency.

The orientation of the house does not lead to the north in the three brick processing locations influenced by the meaning of living owned by the tribe of Makassar in the three brick processing locations because the north gives the meaning of sadness.

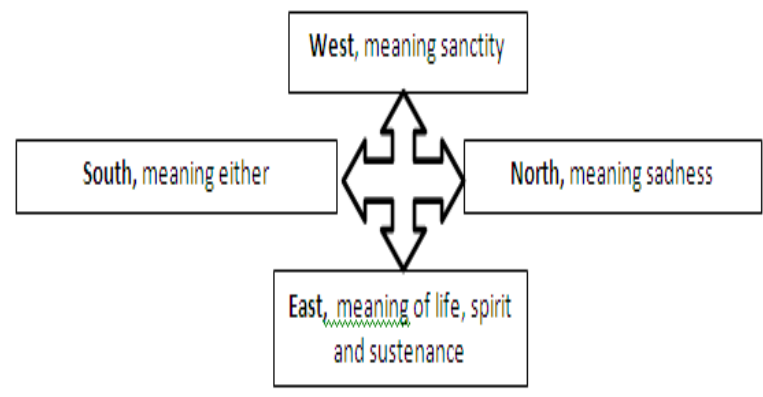

Fig. 11. Meaning of the direction of the wind that is believed Makassar tribe society.

This may also be adapted to the naming of the divided Bontolangkasa village, where the village of Bontolangkasa North and South should be but the 
villagers of Bontolangkasa North do not use the name but the name of Bontolangkasa I village.

\section{Holy Place}

For the orientation of the house to the holy places such as mosques and mushallah only a few houses that lead to the shrine, this is influenced by the pattern of settlements in the hamlet Giring-Giring, village Bontolangkasa and Maccinibaji village pattern centered, spread and linear in the direction.

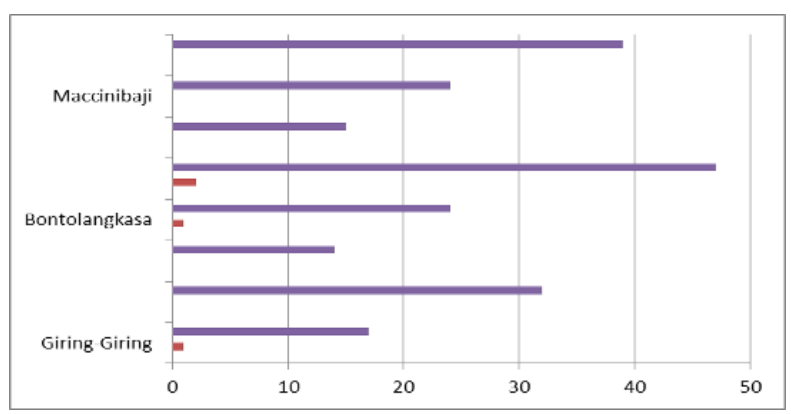

Fig. 12. Graph of home orientation to the shrine in the brick processing settlements of Gowa Regency.

Source: Analysis Result, 2017.

\section{Home Tread Pattern}

The ideal form for home tread patterns is observed through the variables of outer space with kinship indicators, wells / sinks, trees, casual / bale-bale and others. Work location variable of brick processing have indicator of house distance with brick processing location worker while work group variable brick processing with indicator individual, family and group.

Table 2. Ideal Being through Household Pattern in the Brick Plantation Area of Gowa Regency.

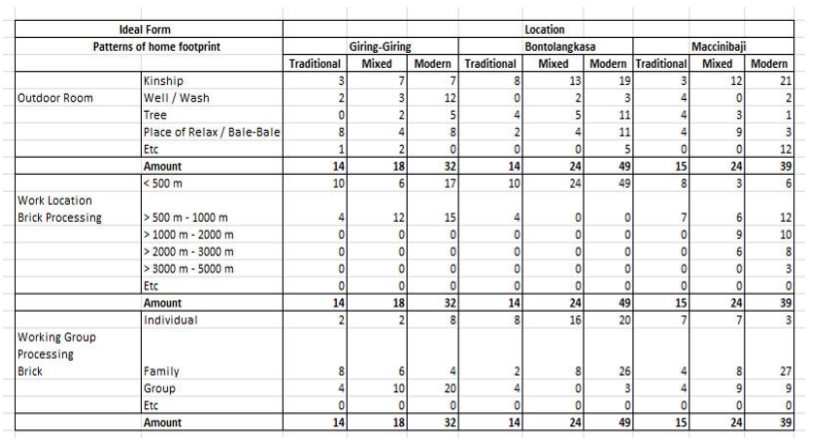

\section{Outdoor Room}

The outdoors analyze the ideal form of the aspect of the place where the social relationship occurs so that the indicator of the outdoor space variables are kinship, well / wash, tree, relaxation and others.

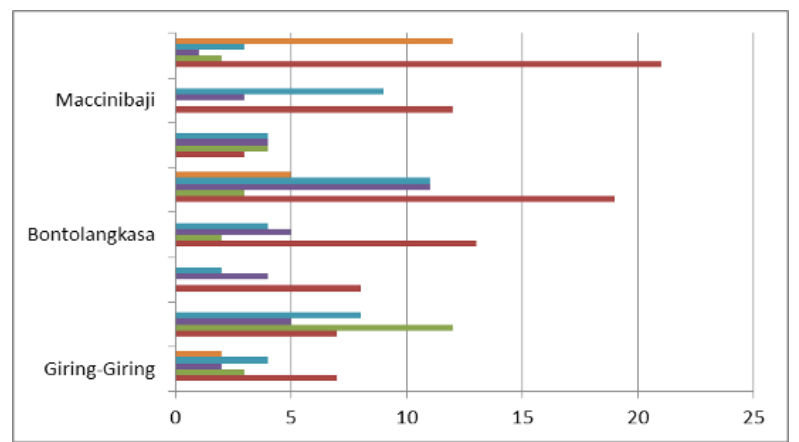

Fig. 13. Graph of home tread pattern to outer space of house in brick processing settlement of Gowa Regency.

Social relation of bricklayer society is happening at kinship level so brick making process can also be done through cooperation between relatives like neighbors, family who live close to brick processing house.

\section{Work Location of Brick Processing}

The location of brick processing work can also affect the pattern of home tread in the ideal shape because the pattern of brick processing behavior adjusted to the ideology of brick processing activity can occur at the location of the work. Location work $<500 \mathrm{~m}$ dominant is in the area of modern house in Bontolangkasa village, it is influenced by the level of brick management activity is very influential with the daily activities where brickmaking activity can be done anytime by penglolahnya.

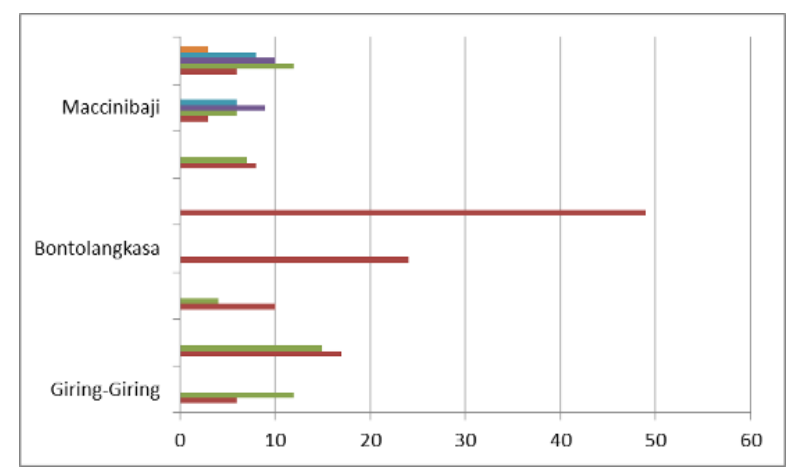

Fig. 14. Graph of home tread pattern to work location in brick processing settlement of Gowa regency.

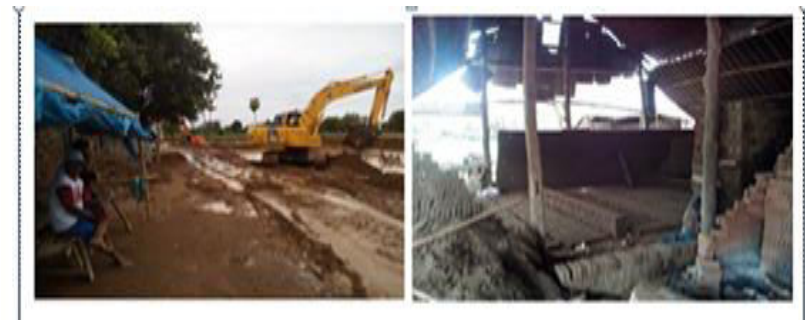

Fig. 15. Processing location and brick material away from the schoolhouse located in Maccibaji village.

The location of the farthest bricklaying workshop is located in Maccinibaji village for a modern house with a distance of $>3000 \mathrm{~m}-5000 \mathrm{~m}$, this is influenced by the distance of the house and the bricklaying place is likely to merge with the place of SDA (Natural Resources) or 
brick material which usually occurs the process of selling the material to other villages.

\section{Working Group of Bricks}

The working group of bricklayers in Gowa Regency is divided into individuals, families, groups and others. In the hamlet Giring-Giring ideal form through working groups are done in groups because in this hamlet the source of brick material is very easy to get because it is in the area of settlement pengelolah so done in groups for the collection of materials and manufacture. This is done by residents who live not far apart or there is a kinship.

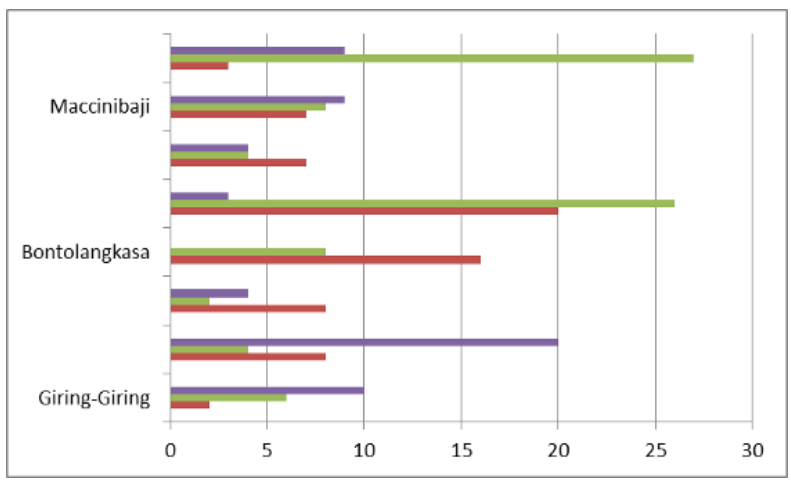

Fig. 16. Graph of home tread pattern to working group in brick processing settlement of Gowa Regency.

For Bontolangkasa and Maccinibaji villages, the brick processing process is mostly done in families because the brick material is in the yard so that the brick management comes from the inhabitants of the house, it is very much happening in the modern house which also do the brick making business in supporting the home economy stairs.

\section{Characteristic of Ideal Behavior of Bricklaying House in Shaping Humanist Shelter}

Residential bricklayers in Gowa Regency, especially in Giring-Giring, Bontolangkasa and Maccinibaji villages, have generally undergone changes both in appearance and form of the house where originally shaped traditional houses ie stage or not the stone has been transformed into a mixed and modern form that made of stone. So that the formation of humanist housing in the settlement is obtained from the ideal form of occupancy (orientation and tread pattern). These two ideal beings are the first part of the process of forming humanist dwelling, because humanis occupancy can occur when the activity and the daily behavior of the brick management can conform with the nature for the human.

Through the analysis of the ideal form of macro space (orientation and tread pattern) residential brick management in shaping humanis shelter, ie in terms of orientation:

1. Natural Resources, affecting the change of bricklaying house because home orientation tends to lead to the place of brick material, there is also the orientation of the house leads to the garden and rice fields so that the ideal form in shaping humanis still obtained by pngelolah stone brick because in economical terms very close to source of supporting livelihood.

2. The road, as the shaper of humanis is obtained through the orientation of the house to the road. The dispersed pattern of settlements directed by the road shows the limits of sensitivity to space and territory that are still intimate to humans, the structure of the village road network based on the circulation paths formed within a traditional village sphere, leading to the limitation of land / soil to be reached by the activity community bricklayers in Gowa District.

3. The wind, which influences the orientation of the bricklaying house still holds on the customs of the Makassar tribe people in the west, east and south. The west, east and south directions give a good meaning to the inhabitants of the house while for the north it gives the meaning of sadness so that many of the brick management elements do not lead north. When connected with the pattern of occupancy and wind direction that comes the wind direction from west to east while the brick processing place in the south so dust and wind from the brick processing direction does not lead directly towards the dwelling. This is in accordance with one of the characteristics of humanist housing that is hygienic.

4. The holy place, located in a brick-processing settlement area, is always placed in a section not in the direction of the brick management because holy places such as mosques and mosques are always expected to be in a clean state, this is very united with the characteristics of humane dwelling.

5. Outer space, consisting of kinship, wells / sinks, trees and lounges / bale-bale is part of the outer space of the bricklaying house that is part of humanist.

6. The location of brick processing work in Gowa Regency is dominant to be close to its residence due to the close location of brick making is very supportive to humanist residential aspects in terms of economic.

7. Working groups of brick processing, mostly done in families so that the prospect of making is done for generations and sustainable to improve the household economy.

Characteristics of the ideal form in shaping humanis in the residential area of bricklaying management can be formed despite changes in shape / appearance of the building. From the macro aspect of the humanist macro space many provide economic and social sustainability value.

\section{Conclusion}

Humanist shelter can be known through the behavior and habits of the community, this can occur in the area of bricklaying settlements although the form of his house has undergone changes and development. 


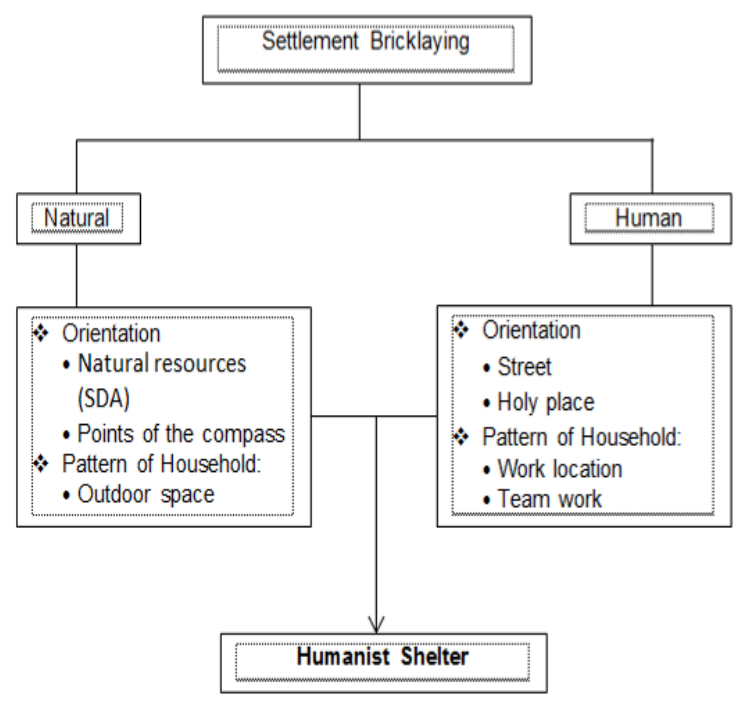

Fig. 14. Humanist Shelter Schemes in the Brick Plantation Settlement of Gowa Regency.

From the ideal form of bricklaying house in Gowa regency which form humanis occupancy characteristic can be known through macro space that is orientation and pattern of home tread which still maintain environmental, social and economic aspects in brick processing settlement area.

In shaping humanist residence in the residential areas of brick processing begins from the behavior and activities of society or human in everyday life.

\section{References}

Altman, Irwan and Chemers, Martin. 1980. Culture and Environment, First Published by Canbridge University Press, California.

Hali, Damianus J. (2008). Humanism and Global Civilization, in Humanities and Its Relevance to Education. Sugiharto, Bambang, ed, Jalasutra , print I. Yogyakarta

Koentjaraningrat., 1976. Human and Culture in Indonesia, Publisher Djambatan, Jakarta.

LP2B Study Kab. Gowa South Sulawesi, 2014

Mardanas, Izarwisman and friends. 1985, Traditional Architecture of South Sulawesi Region, Dep. P and K, Jakarta.

Moleong, J., Lexy. 2001, Qualitative Research Methodology, Rosdakarya, Bandung.

Muri Yusuf. 2015. Quantitative Research Methods, Qualitative and Joint Research.

Prasetyo, Bambang and Jannah LM (2005), Quantitative Research Methods, PT. Raja Grafindo Persada, Jakarta.

Soerjono S and Sulistyawaty. 2014. Sociology an Introduction. PT. Raja Grafindo Persada. Jakarta.

Soeroto. 2003. Jambi Malay Settlement Pattern, Thesis, Diponegoro University, Semarang.

Wahid, Sugira. 2007. Makassar Man, Reflection, Makassar. 